LOPEZ-RIBA, José María: "Distributive justice and police legitimacy: the demographic

and geographical distribution of police ID checks in Spain Justicia distributive y

legitimidad policial: la distribución demográfica y geográfica de las identificaciones

policiales en España"

Polít. Crim. Vol. 16, № 31 (Junio 2021), Art. 6, pp. 146-163

[http://politcrim.com/wp-content/uploads/2021/05/Vol16N31A6.pdf]

\title{
Distributive justice and police legitimacy: the demographic and geographical distribution of police ID checks in Spain
}

\section{Justicia distributiva y legitimidad policial: la distribución demográfica y geográfica de las identificaciones policiales en España}

\author{
José María López-Riba \\ Universidad Pompeu Fabra \\ josemaria.lopez@upf.edu \\ https://orcid.org/0000-0003-0520-710X
}

Reception date: $05 / 28 / 2020$

Acceptance date: 12/03/2020

\begin{abstract}
The distribution of police activity throughout society is a key issue for distributive justice and police legitimacy. This article presents two studies on the distribution of police identification checks in Catalonia (Spain) using data provided by Mossos d'Esquadra (the Catalan Regional Police). The first study explores the demographic distribution of ID checks, in other words, which groups of people are more likely to be stopped and have their identification checked by police. The second study examines the geographical distribution, that is, in which places are there greater concentrations of ID checks. The results show that with regards to demographics, men, young people and foreign people are associated with higher levels of ID checks. In addition, the geographical distribution is not primarily driven by crime rates, thus, in general, it seems that the distribution of ID checks is not as strongly related to crime as may be expected.
\end{abstract}

Keywords: ID checks, police stops, policing, distributive justice, police legitimacy.

\section{Resumen}

La distribución de la actividad policial a través de los grupos sociales es un aspecto clave de la justicia distributiva y la legitimidad policial. Este artículo presenta dos estudios sobre la distribución de las identificaciones policiales en Cataluña (España) que hacen uso de datos proporcionados por los Mossos d'Esquadra (la policía de Cataluña). El primer estudio explora la distribución demográfica de las identificaciones policiales; o en otras palabras, a qué grupos de personas es más probable que la policía les pare por la calle y les pida su identificación. El segundo estudio examina la distribución geográfica; es decir, en qué lugares hay mayores concentraciones de identificaciones policiales. Respecto a la distribución demográfica, los hombres, los jóvenes y las personas extranjeras presentan tasas mayores de identificaciones. Además, la distribución geográfica de las identificaciones no está guiada principalmente por las tasas de delincuencia. Por lo tanto, se concluye que parece 


\section{Polít. Crim. Vol. 16, No 31 (Junio 2021), Art. 6, pp. 146-163 [http://politcrim.com/wp-content/uploads/2021/05/Vol16N31A6.pdf]}

que la distribución de las identificaciones no está relacionada de forma robusta con la delincuencia como cabría esperar.

Palabras clave: identificaciones policiales, paradas policiales, función policial, justicia distributiva, legitimidad policial.

\section{Police ID checks in Spain}

Police identity checks (ID checks) are the power conferred to the police to stop people in the street and ask them to show their identity documents. According to Spanish legislation (Public Safety Act 2015), a police officer can conduct an ID check in two scenarios: i) when there is evidence of the commission of an infraction (this could be criminal or administrative); ii) when a police officer considers it necessary to prevent a crime. ${ }^{1}$ Therefore, in the Spanish legislation, as well as in other countries, ID checks are mainly conceived as a crime control strategy in terms of either detection or prevention.

Despite being extensively studied in international criminological literature, ID checks are an under-researched area in Spain. There are a few notable exceptions that study some specific aspects of ID checks, such as their regulation, ${ }^{2}$ the use of ethnic profiling ${ }^{3}$ and their effectiveness in detecting infractions. ${ }^{4}$ Aside from these examples, in comparison to international studies, Spanish criminology has paid little attention to police ID checks despite many reasons that suggest their potential criminological relevance.

The first of these reasons is their extensive use in comparison to other countries. ${ }^{5}$ In 2015 , the Civil Guard and the Spanish National Police (the two state police forces) alone ${ }^{6}$ conducted around 6.5 million ID checks. ${ }^{7}$ The second group of reasons are the controversies surrounding the practice of ID checks: their use in controlling irregular migration, ${ }^{8}$ the use of ethnic profiling ${ }^{9}$ and their apparent ineffectiveness with regards to detecting infractions. ${ }^{10}$ These issues have been reported by different organizations and institutions at the national and international level. ${ }^{11}$ Finally, the third reason is that some authors claim that by analysing police stops, such as the characteristics of the context in which they take place (for example,

\footnotetext{
${ }^{1}$ There are other scenarios provided by the law in which the police can conduct collective ID checks, but they are reserved for exceptional cases: the investigation and prevention of serious crimes and crimes that generate social alarm.

${ }^{2}$ For example: DE LA SERNA (2017), passim; RÍOS et al. (2015), pp. 43-85.

${ }^{3}$ For example: GARCÍA et al. (2013), passim; APDHA and IPAZ-UGR (2016), passim; FRA (2010), passim.

${ }^{4}$ For example: GARCÍA et al. (2013), passim; GARCÍA et al. (2016), passim; SCHMITT y PERNAS (2008), passim.

${ }^{5}$ LÓPEZ-RIBA (2019), p. 194.

${ }^{6}$ It should be noted that in Spain there are also regional and local police forces.

${ }^{7}$ MINISTRY OF HOME AFFAIRS (2016), p. 438.

${ }^{8}$ DE LA SERNA (2017), passim; MARTÍNEZ and SÁNCHEZ (2013), passim.

${ }^{9}$ See note 3 .

${ }^{10}$ See note 4.

${ }^{11}$ For example: AMNISTÍA INTERNACIONAL (2011), passim; CERD (2016), p. 5; DEFENSOR DEL PUEBLO (2013), p. 55; ECRI (2018), p 16.
} 
high discretion or low visibility) and the aforementioned controversies, it is possible to gain a better understanding of how policing is conducted in our societies. ${ }^{12}$

For the reasons described above, the current study has been designed to examine the demographic and geographical distribution of ID checks. This is a relevant topic because analysing the demographic and geographical distribution can help to understand the way in which this power is wielded in daily police work. Moreover, the distribution of ID checks throughout society is strongly connected with the distributive justice of policing and its implications for police legitimacy.

\section{Demographic and geographical distribution of police stops}

There are different theoretical approaches that can help to understand the social, demographic, and geographical distribution of ID checks. In sum, there are two principal perspectives. The first perspective, the consensus perspective, conceives police stops as having the specific aim of controlling crime, as claimed by the police themselves and set out in legislation. The second viewpoint understands police stops as a tool for controlling behaviours and people perceived as dangerous to the ideal of social order fostered by the police; thus, police stops are conceived as a tool for order maintenance rather than crime control. ${ }^{13}$

The police deployment theory assumes it is generally agreed that the police should focus their activity on crime control. This theory proposes that police activity, which includes police stops, tends to be concentrated in those areas with high levels of crime as identified through the information gathered by the police and reports from citizens. ${ }^{14}$ Therefore, ID checks are more likely in areas highlighted by police intelligence as problematic in terms of crime and areas where there are more crime-related requests by citizens and, therefore, people who live or transit these areas are more likely to be stopped by the police. ${ }^{15}$ This theory is consistent with the common-sense view and the official institutional narratives about policing. ${ }^{16}$ Broken windows theory adds to this perspective as disorderly behaviour should also be a target of the police because it is a precursor of crime. Thus, proactive strategies focused on disorderly behaviours and zones are necessary to prevent serious crime. Within these police strategies, police stops are a key resource because of their proactive and visible character. ${ }^{17}$

In contrast, conflict perspective assumes that the police are not simply guided by police intelligence and calls from citizens, but they also proactively control "dangerous" and "disorderly" people who represent a threat to the dominant groups. These groups use law enforcement agencies to minimise threats to their interests posed by those who they label as "dangerous". The police have incentives to do this because they seek practices that minimise conflicts and maximize rewards and "dangerous" people tend to belong to groups with no

\footnotetext{
${ }^{12}$ BOWLING and MARKS (2015), passim; BRADFORD (2017), passim; BRADFORD and LOADER (2016), passim; DELSOL (2015), passim.

${ }^{13}$ RENAUER (2012), passim.

14 These deployment decisions may be based on other decisions besides the level of crime. For a general discussion see for example REINER (2010), passim.

${ }^{15}$ RENAUER (2012), passim.

${ }^{16}$ BRADFORD and LOADER (2016), p. 252.

${ }^{17}$ BOWLING and MARKS (2015), passim; FAGAN et al. (2010), passim.
} 


\section{Polít. Crim. Vol. 16, No 31 (Junio 2021), Art. 6, pp. 146-163 [http://politcrim.com/wp-content/uploads/2021/05/Vol16N31A6.pdf]}

political voice and little power to resist. The principal distinction between consensus and conflict perspectives is that the first assumes crime is concentrated in specific areas and groups of people, whereas the second assumes crime is spread across areas and groups but the police tend to tolerate the criminal behaviour of some groups while focussing their activity on others. ${ }^{18}$

Three theories have been proposed in the conflict perspective framework. Firstly, racial threat theory states that a proportional increase of people from racial and ethnic minorities could be viewed as a political or economic threat by prevailing groups and the police will act to mitigate that threat, thus, it is expected that the police will concentrate their activity in those areas with a greater proportion of people belonging to ethnic and racial minorities. Secondly, out of place theory (or the incongruity thesis) argues that the police focus their attention on people who do not fit what is supposed to be normal in specific times and places. For example, black people in predominately white neighbourhoods at night are more likely to attract the attention of the police (and the contrary should also be true). And finally, social conditioning theory affirms that some groups (such as some ethnic minorities) and some areas are stereotypically linked to social problems and crime and those prejudices influence police behaviour ${ }^{19}$.

Furthermore, some authors have argued that the police use their resources (including police stops) to discipline some groups, especially young people from the working classes who spend considerable time on the streets. ${ }^{20}$ From this point of view, ID checks are not used as the main resource to start a criminal process to determine criminal culpability but as a way to remind some communities that they are under permanent and strict police supervision and they cannot transgress existing social categories and boundaries. ${ }^{21}$ This explanation fits with what some authors have found regarding the police control of foreign people in Spain. ${ }^{22}$

From a broader perspective, considering police stops as the main resource available to the police can be linked to research that claims that the principal function of the police is to maintain social order. ${ }^{23}$ Therefore, it is viewed as normal that police stops have objectives other than controlling crime. ${ }^{24}$ Finally, some authors ${ }^{25}$ claim that in order to see the whole picture, those explanations have to be combined with theories of racial bias and institutional racism to account for the fact that ethnic minorities are a predilected target of police stops.

\footnotetext{
18 BRADFORD and LOADER (2016), passim; MOONEY and YOUNG (1999), passim; PETROCELLI, PIQUERO and SMITH (2003), passim; RENAUER (2012), passim.

${ }^{19}$ See note 18.

${ }^{20}$ MCARA and MCVIE (2005), passim; MEDINA (2014), passim; MOONEY and YOUNG (1999), passim.

${ }^{21}$ CHOONGH (1998), passim.

${ }^{22}$ ESCUDERO, GARCÍA and SLEPOY (2015), p. 192-193; GARCÍA (2012), p. 575.

${ }^{23}$ For example: BRODEUR (2010), passim.

${ }^{24}$ BRADFORD (2017), passim; TIRATELLI et al. (2018), p. 1227.

${ }^{25}$ For example: BRADFORD and LOADER (2016), p. 260.
} 


\section{Methods}

\subsection{Objective and hypotheses}

The principal objective of the present article is to analyse the demographic and geographical distribution of ID checks to establish if these are used only as a tool for crime prevention/detection or if ID checks have other wider functions regarding order maintenance. If ID checks are mainly a crime control tool, one can expect them to be concentrated in high crime areas and amongst those groups of people who commit more crimes. On the other hand, if they are used as an order maintenance tool, their distribution should be explained by other variables such as demographics (gender, age, ethnicity, race, etc.) or socioeconomic status.

On the basis of the theoretical perspectives presented previously, the proposed hypotheses are the following:

$\mathrm{H}_{1}$ : ID checks are greater for those groups of people who commit more crimes and in those places with higher crime rates.

$\mathrm{H}_{2}$ : ID checks are affected by other demographic and socioeconomic factors (such as gender, age, nationality and income) independently of the crimes committed by different groups of people and the level of crime in different areas.

\subsection{Variables}

In order to test these hypotheses, data from Mossos d'Esquadra was requested on the demographics - age, sex, nationality ${ }^{26}$ — of people stopped and identified by the police in 2015 and the Police Basic Area $(A B P)^{27}$ in which people had their IDs checked. Subsequently, the rates per 1,000 inhabitants were calculated using the data on resident population and age, sex, nationality and country of birth provided by the Catalan Institute of Statistics ${ }^{28}$ and Barcelona City Council. ${ }^{29}$ Moreover, to study the geographical distribution of ID checks, the following variables were included at ABP level using data from the Business

\footnotetext{
${ }^{26}$ Nationality was used because data about ethnicity is not available.

${ }^{27} \mathrm{An}$ ABP is the "smallest geographical and population area provided with basic police services for prevention, public safety, traffic control and investigation. The basic service is composed of: one the one hand, a main Mossos d'Esquadra station as well as other decentralized police stations depending on the necessities and the extension of the area; and, on the other hand, the local police forces established in that territory coordinated by local control boards" (MOSSOS D'ESQUADRA, 2018).

${ }^{28} \mathrm{https}: / / \mathrm{www} . \mathrm{idescat} . \mathrm{cat} / \mathrm{pub} / \mathrm{id}=\mathrm{pmh} \& \mathrm{n}=446 \& \mathrm{by}=$ mun\&t=201500 [last check on April 26, 2021$]$. http://www.idescat.cat/pub/?id=pmh\&n=7567\&t=201500\&col=3\&by=mun\#Plegable=geo [last check on April 26, 2021]. https://www.idescat.cat/pub/?id=pmh\&n=1180\&t=201500\&col=3\&by=mun [last check on April 26, 2021$].$ ${ }^{29} \mathrm{http}: / /$ www.bcn.cat/estadistica/catala/dades/tpob/pad/padro/a2015/edat/edata02.htm [last check on 26, 2021]. http://www.bcn.cat/estadistica/catala/dades/anuaris/anuari16/cap02/C020107.htm [last check on April 26, 2021]

http://www.bcn.cat/estadistica/catala/dades/anuaris/anuari16/cap02/C020102.htm [last check on April 26, 2021].
} 


\section{Polít. Crim. Vol. 16, № 31 (Junio 2021), Art. 6, pp. 146-163 [http://politcrim.com/wp-content/uploads/2021/05/Vol16N31A6.pdf]}

and Labour Observatory, ${ }^{30}$ Catalan Institute of Statistics ${ }^{31}$ and Barcelona City Council ${ }^{32}$ : the rate of ID checks, percentage of the population that are male; percentage of young people (from 16 to 29); percentage of people born in a non-Western country; and disposable household income. Finally, the victimization rate at ABP level was calculated based on data from the Catalan Public Security Survey $2015^{33}$ and Barcelona City Council. ${ }^{34}$ All the aforementioned variables were collected for 2015 because of their greater availability. ${ }^{35}$

\subsection{Analysis}

The results are presented in two parts. The first focusses on the social distribution of ID checks by calculating and comparing the rates of people subject to identification by police according to sex, age and nationality. In the second part the geographical distribution is tested using ordinary multiple regression models with variables at ABP level. ${ }^{36}$

\section{Results}

\subsection{Demographic distribution}

To account for the demographic distribution, the following graphs present the different rates of people stopped and identified by the police according to their representation in the resident population..$^{37}$

\subsubsection{Sex}

Graph 1 shows that the rate of people stopped and identified by police is higher for men than for women. For every 1,000 men in the resident population 120.6 were identified by the police, whereas this rate was 38.6 for women. Therefore, the rate for men was nearly 4 times higher.

\footnotetext{
${ }^{30}$ BUSINESS AND LABOUR OBSERVATORY (2016), passim.

${ }^{31}$ See note 24 and https://www.idescat.cat/pub/?id=rfdbc\&n=8224\&by=mun [last check on April 26, 2021 ].

32 See note 27 and http://www.bcn.cat/estadistica/catala/dades/ttreball/mov_lab/atur/evolucio/dte/pesatdt.htm [last on $\quad$ check $\quad$ April 2021$].$ http://ajuntament.barcelona.cat/barcelonaeconomia/sites/default/files/RFD_2014_informe.pdf [last check on March 21, 2021].

${ }^{33}$ Data provided by the Catalan Department of Home Affairs.

${ }^{34}$ http://www.bcn.cat/estadistica/catala/dades/anuaris/anuari17/cap08/C0805010.htm [last check on April 26, 2021]. [Due to the lack of data for 2015 a mean of years 2012, 2013, 2014 and 2016 was calculated.]

35 The ABP level data is approximate because in the databases consulted data is not disaggregated by ABP. An approximate calculus was carried out using data for the county, cities and districts of Barcelona.

${ }^{36}$ These regressions were performed in the software Stata 14.

${ }^{37}$ I used the resident population as it was not possible to access data for 'available population'. Nevertheless, some authors, such as BOWLING and PHILLIPS (2007), pp. 952-953, claim that the resident population is the best indicator to determine how different groups of people experience police stops in daily life.
} 


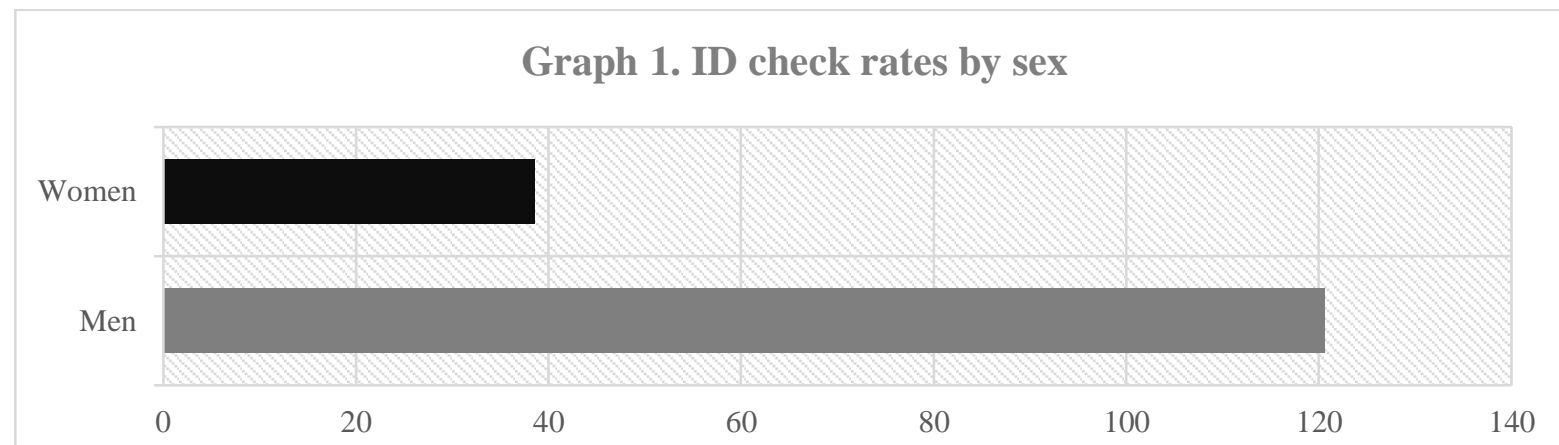

Source: Produced by the author using data from the Catalan Department of Home Affairs.

\subsubsection{Age}

Graph 2 shows that young people are subject to disproportionately more ID checks by the police. The rate of people up to 15 years old identified by the police was 7.2 (for every 1,000 people from 0 to 15 years), for people between 16 and 29 it was 195.7, for people between 30 and 59 it was 96.6 and for people older than 60 it was 23.9. Therefore, young people between 16 and 29 are identified nearly 19 times more than children (up to 15 years), 2 times more than the people in the third category (between 30 and 59) and 10 times more than elderly people (more than 60 years old).

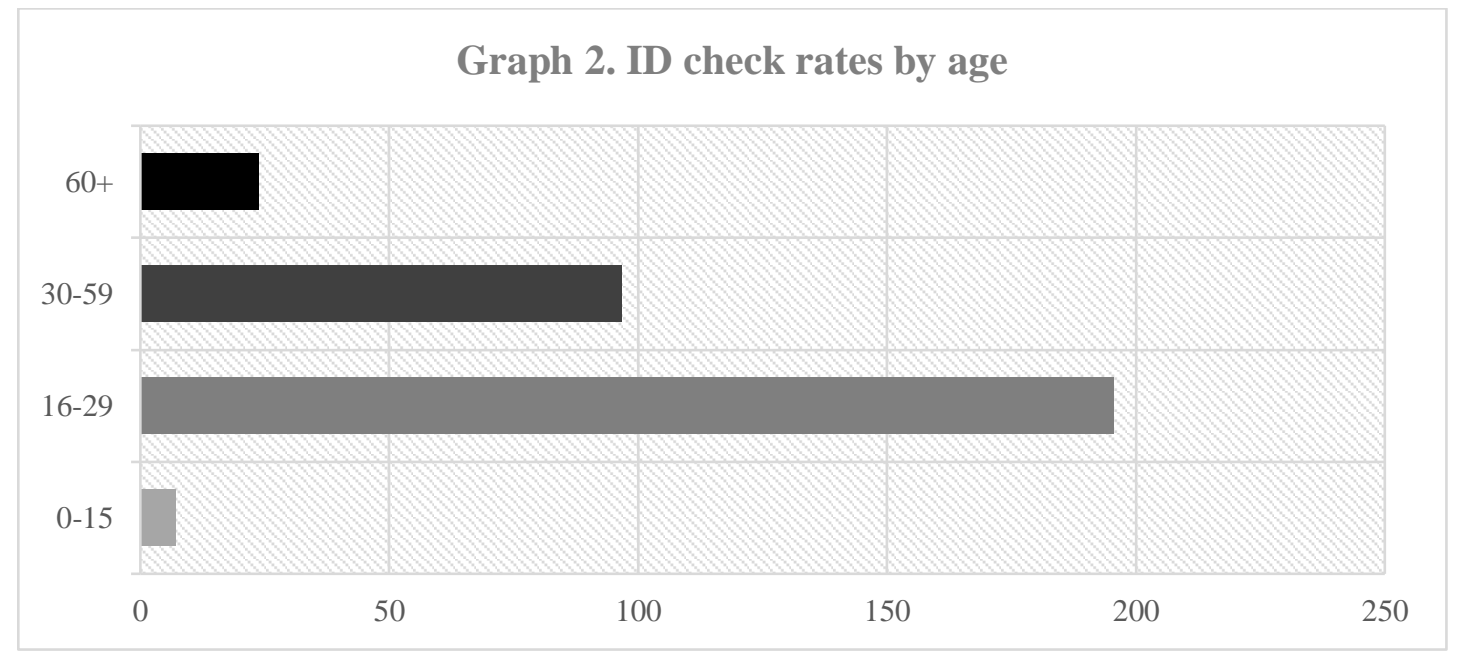

Source: Produced by the author using data from the Catalan Department of Home Affairs.

\subsubsection{Nationality}

Regarding nationality, Graph 3 shows that in general people who are not of Spanish nationality are stopped more often than Spanish nationals. The rate of identified Spanish people was 58.2 (for every 1,000 Spanish people), for people from North America it was 76.3, for people from Eastern Asia it was 77.7, for people from Western and North Europe it was 116.8, for people from Australasia it was 141.1, for people from Central and South Africa it was 149, for people from Central and South Asia it was 154.2, for people from Central and 


\section{Polít. Crim. Vol. 16, No 31 (Junio 2021), Art. 6, pp. 146-163 [http://politcrim.com/wp-content/uploads/2021/05/Vol16N31A6.pdf]}

South America it was 232.8, for people from North Africa it was 291.1 and for people from Eastern and Baltic Europe it was 309.6.

As can be seen, this disproportion depends on nationality. Table 1 specifies the disproportions regarding Spanish people. The disproportions in police identifications can be up to 5 times higher for people who come from countries in North Africa or Eastern Europe, and nearly 4 times greater for people who come from countries in Central and South America. People from Western and North Europe countries, Australasia, Central and South Africa and Central and South Asia are identified 2 times more than Spanish people. People from North America or Eastern Asian countries have their IDs checked more than Spanish people but in a lower proportion compared to the rest of the nationalities.

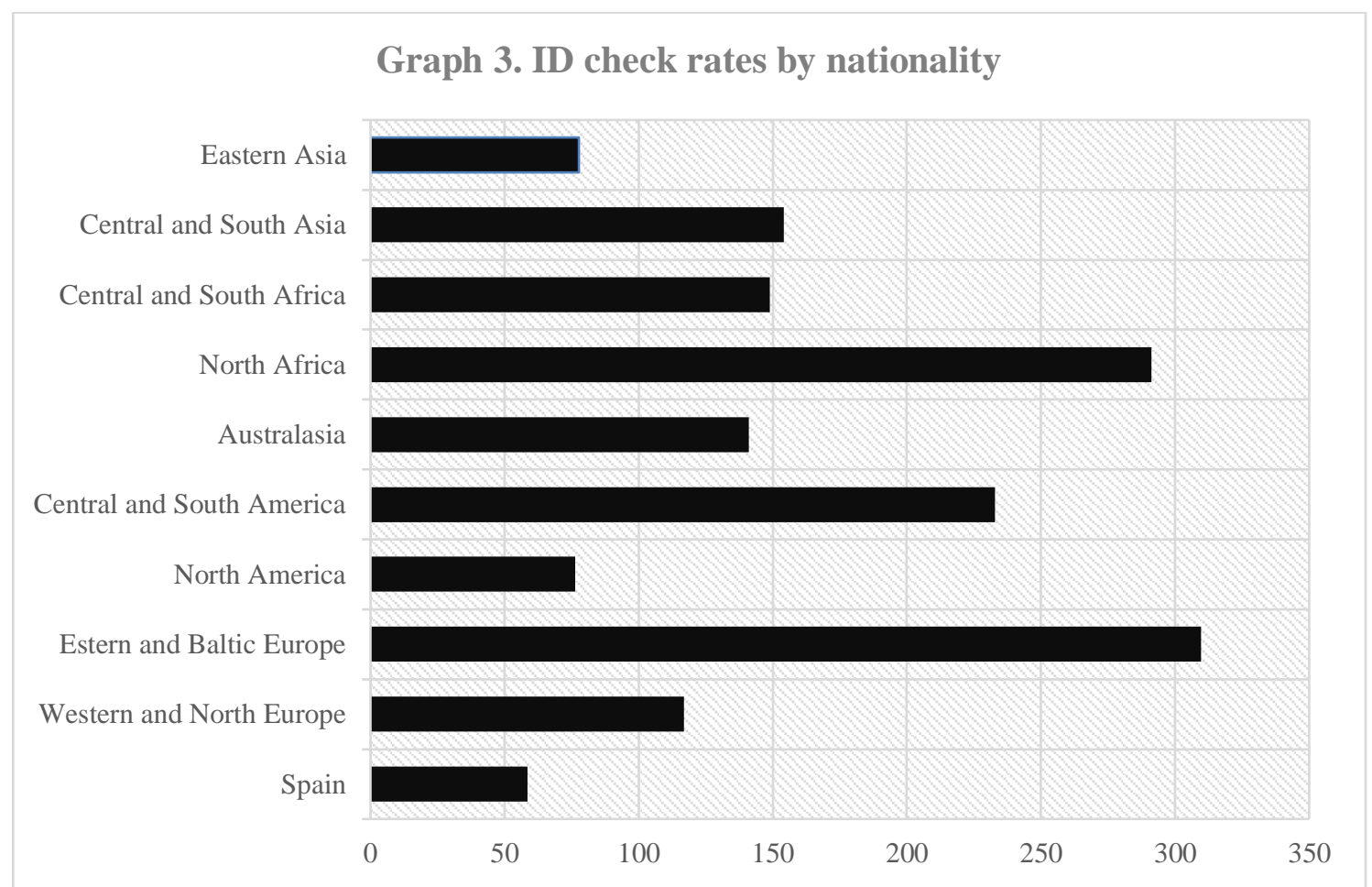

Source: Produced by the author using data from the Catalan Department of Home Affairs. 
Table 1. Disproportion in ID check rates by nationality in comparison with ID checks for Spanish people.

\begin{tabular}{|c|c|}
\hline Nationality & Disproportion \\
\hline Spain & - \\
\hline Eastern and Baltic Europe & 5,2 \\
\hline North Africa & 4,9 \\
\hline Central and South America & 3,7 \\
\hline Central and South Africa & 2,6 \\
\hline Central and South Asia & 2,5 \\
\hline Australasia & 2,3 \\
\hline Western and North Europe & 1,9 \\
\hline Eastern Asia & 1,4 \\
\hline North America & 1,3 \\
\hline
\end{tabular}

\subsection{Geographical distribution}

In reference to the geographical distribution, Table 2 displays three regression models in which the dependent variable is the ID check rate per 1,000 inhabitants at ABP level. ${ }^{38}$

The first model (M1) includes the crime rate and the rate of police officers per 1,000 inhabitants at ABP level. ${ }^{39}$ In this model only the rate of police officers has a positive significant effect. This means that more police officers led to more people being stopped and identified by the police independently of the effect of the crime rate.

The second model (M2) consists of the independent variables percentage of males, percentage of young people and percentage of people born in a non-Western country ${ }^{40}$ (countries which does not belong to Western Europe, North America, Australia or New Zealand), as well as the disposable household income at ABP level. In this case no independent variable has a significant effect. Regarding the goodness of fit of the models, model 1 (Adjusted $\mathrm{R}^{2}=0.22$ ) is better than model 2 (Adjusted $\mathrm{R}^{2}=0.14$ ) explaining the variation of the dependent variable.

\footnotetext{
${ }^{38}$ Converted to the natural logarithm to reduce asymmetry.

${ }^{39}$ Calculated from aforementioned data and available data on the open data website of Mossos d'Esquadra: https://mossos.gencat.cat/ca/els_mossos_desquadra/indicadors_i_qualitat/dades_obertes/cataleg_dades_oberte s/ [last check on April 26, 2021].

40 Taking into account the results exposed in the Graph 3 and the Table 1.
} 
Table 2. Multiple regression models for the distribution of ID checks by ABP.

\begin{tabular}{|l|c|c|c|}
\hline DV: ID check rate per 1,000 inhabitants (In) & M1 & M2 & M3a \\
\hline Crime rate per 1,000 inh. & 0.001 & & $0.003^{*}$ \\
\hline & $(0.001)$ & & $(0.002)$ \\
\hline Police officers rate per 1,000 inh. & $0.19^{* * *}$ & & $0.17^{* * *}$ \\
\hline & $(0.05)$ & & $(0.05)$ \\
\hline \% men & & 0.05 & 0.009 \\
\hline & & $(0.03)$ & $(0.03)$ \\
\hline \% young people & & 0.09 & $0.08^{*}$ \\
\hline & & $(0.05)$ & $(0.05)$ \\
\hline \% people born in a non-Western Country & & -0.01 & -0.03 \\
\hline & & $(0.01)$ & $(0.01)$ \\
\hline Disposable household income & & -0.03 & $-0.03 *$ \\
\hline & & $(0.02)$ & $(0.01)$ \\
\hline Constant & $4.30^{* * *}$ & 1.79 & $3.61 *$ \\
\hline & $0.11)$ & $(1.68)$ & $(1.59)$ \\
\hline $\mathrm{N}$ & 59 & 59 & 59 \\
\hline $\mathrm{R}^{2}$ & 0.25 & 0.20 & 0.39 \\
\hline Adjusted $\mathrm{R}^{2}$ & 0.22 & 0.14 & 0.32 \\
\hline Stan
\end{tabular}

Standard errors in parentheses.

$* \mathrm{p}<0.05, * * \mathrm{p}<0.01, * * * \mathrm{p}<0.001$

Once all independent variables of model 1 and 2 are combined in one model, as found in the third model (M3a), the number of police officers remains significant in the same direction and the crime rate (positively), the percentage of young people (positively) and the disposable household income (negatively) become significant. In reference with the anticipated hypotheses, higher levels of crime predicted more ID checks by the police, as expected by $\mathrm{H}_{1}$ (ID checks as a tool for crime control). However, as expected by $\mathrm{H}_{2}$ (ID checks as a tool for order maintenance), the percentage of young people and the disposable household income also have an independent effect. In the first case, the effect is positive, pointing out that more young people in an ABP is related with a higher rate of ID checks. In the second case the effect is negative, which means that in those ABP with higher income the rate of ID checks is significantly lower. Model 3a is significantly better in terms of goodness of fit (Adjusted $\mathrm{R}^{2}=0.32$ ) than the previous two models (models 1 and 2).

Due to the fact that foreign people in Catalonia tend to be younger than people with Spanish nationality ${ }^{41}$, an alternative for model $3 a$, the model $3 b$, with an interaction effect between the percentage of young people and the percentage of people born in a non-Western country can be seen in the Table 3 . The crime rate, the police officers rate and the household income keep their significant effects in the same direction, whereas the percentage of young people loses its significance. This is probably because this model is accounting that the effect of the percentage of young people can change at different values of the percentage of people born in a non-Western country (or the other way around) but that effect is also not significant.

${ }^{41}$ See https://www.idescat.cat/poblacioestrangera/?b=1 [last check on March 21, 2021]. 
Model $3 b$ (Adjusted $\mathrm{R}^{2}=0.32$ ) is similar than model 3a explaining the variation of the identified people.

Table 3. Multiple regression model for the distribution of ID checks by ABP with interaction effects.

\begin{tabular}{|l|c|}
\hline $\begin{array}{l}\text { DV: identified people rate per 1,000 } \\
\text { inhabitants (In) }\end{array}$ & M3b \\
\hline Crime rate per 1,000 inh. & $0.004^{*}$ \\
\hline & $0.002)$ \\
\hline Police officers rate per 1,000 inh. & $0.18^{* * *}$ \\
\hline & $(0.05)$ \\
\hline \% men & 0.02 \\
\hline & $(0.03)$ \\
\hline \% young people & 0.11 \\
\hline & $(0.06)$ \\
\hline$\%$ people born in a non-Western country & 0.02 \\
\hline & $(0.06)$ \\
\hline$\%$ young * pbn-Wc & -0.004 \\
\hline & $(0.004)$ \\
\hline Disposable household income & $-0.03 *$ \\
\hline & $(0.02)$ \\
\hline Constant & 2.76 \\
\hline & $(1.83)$ \\
\hline $\mathrm{N}$ & 59 \\
\hline $\mathrm{R}^{2}$ & 0.40 \\
\hline Adjusted $\mathrm{R}^{2}$ & 0.32 \\
\hline Standard & \\
\hline
\end{tabular}

Standard errors in parentheses.

$* \mathrm{p}<0.05, * * \mathrm{p}<0.01, * * * \mathrm{p}<0.001$

Nevertheless, it is important to consider that the crimes recorded by the police cannot be taken as an independent indicator of the level of crime in an ABP, as done in models 1, 3a and $3 \mathrm{~b}$. Its effect is endogenous with respect to the dependent variable (the two variables partially measure the same), because ID checks produce recorded crimes (Bradford, 2017). Therefore, in the model 3c, which can be observed in Table 4, the crime rate is replaced by the victimization rate as an independent indicator of crime level in the ABP. Having carried out this replacement, the victimization rate has a non-significant negative effect, contrary to expected by $\mathrm{H}_{1}$ (crime control), and the only variable that is still significantly correlated with ID checks is the rate of police officers. As mentioned previously, it is difficult to observe significant relationships due to the small number of ABP (59). For this reason, it is also important to look at the directions of the effects. Excluding the percentage of people born in a non-Western country (which has a negative effect ${ }^{42}$ ), the positive relationships regarding the percentage of men, the percentage of young people (and its interaction with the

${ }^{42}$ As in the previous model the effect was positive this negative effect could probably be because of the correlation with the victimization rate $(\mathrm{r}=0,52)$. 
percentage of people born in a non-Western country) and the disposable household income are as expected in the order-maintenance hypothesis $\left(\mathrm{H}_{2}\right)$. Model $3 \mathrm{c}$ is slightly worse than model $3 \mathrm{a}$ and $3 \mathrm{~b}$ in terms of goodness of fit (Adjusted $\mathrm{R}^{2}=0.30$ ), but this could be the result of the endogenous effects of crime rates as measured by crime recorded by the police.

Table 4. Multiple regression model for the distribution of ID checks by ABP with the victimization rate.

\begin{tabular}{|c|c|}
\hline $\begin{array}{l}\text { DV: identified people rate per } 1,000 \\
\text { inhabitants (ln) }\end{array}$ & M3c \\
\hline \multirow[t]{2}{*}{ Victimization rate } & -0.02 \\
\hline & $(0.01)$ \\
\hline \multirow[t]{2}{*}{ Police officers rate per 1,000 inh. } & $0.15^{* *}$ \\
\hline & $(0.05)$ \\
\hline \multirow[t]{2}{*}{$\%$ men } & -0.01 \\
\hline & $(0.04)$ \\
\hline \multirow[t]{2}{*}{$\%$ young people } & 0.06 \\
\hline & $(0.05)$ \\
\hline \multirow[t]{2}{*}{$\%$ people born in a non-Western Country } & -0.05 \\
\hline & $(0.05)$ \\
\hline \multirow[t]{2}{*}{$\%$ young $*$ pbn-Wc } & 0.003 \\
\hline & $(0.003)$ \\
\hline \multirow[t]{2}{*}{ Disposable household income } & -0.02 \\
\hline & $(0.02)$ \\
\hline \multirow[t]{2}{*}{ Constant } & $4.48^{*}$ \\
\hline & $(1.95)$ \\
\hline $\mathrm{N}$ & 59 \\
\hline $\mathrm{R}^{2}$ & 0.38 \\
\hline Adjusted $\mathrm{R}^{2}$ & 0.30 \\
\hline
\end{tabular}

\section{Discussion}

Men being stopped by police more frequently than women is consistent with previous international research..$^{43}$ And it can be explained because there is criminological consensus that crime rates for men are higher than for women. ${ }^{44}$ Thus, this finding fits with the crime control hypothesis $\left(\mathrm{H}_{1}\right)$.

The rate of ID checks is also greater for young people, as seen in previous research, ${ }^{45}$ and this most probably occurs for the same reasons why men are stopped more often: young

\footnotetext{
${ }^{43}$ For example: GARCÍA et al. (2013), passim; BRADFORD (2017), passim; BRADFORD and LOADER (2016), passim; FRA (2010), passim; MEDINA (2014), passim; MOONEY and YOUNG (1999), passim.

${ }^{44}$ FERNÁNDEZ-MOLINA and BARTOLOMÉ (2018), p. 5.

${ }^{45}$ For example: GARCÍA et al. (2013), passim; BRADFORD (2017), passim; FRA (2010), passim; MEDINA (2014), passim; MOONEY and YOUNG (1999), passim; MURRAY (2014), passim; PEAUCELLIER, SPILKA, JOBARD and LÉVY (2016), passim; TYLER, FAGAN and GELLER (2014), passim.
} 
people are comparatively more involved in the commission of crimes. ${ }^{46}$ The police stopping and identifying more young people appears to support the crime control hypothesis $\left(\mathrm{H}_{1}\right)$. However, we might also ask if the police have a lower degree of tolerance with the behaviour of young people or if the police carry out more intensive control of young people to make them internalize the social order that the police promote, particularly with regards to working class youth who spend more time on the street. ${ }^{47}$

The fact that men and young people are stopped more often by the police is a constant in research about police stops. And it is possible to explain this by the fact that comparatively they commit more crimes ${ }^{48}$ thus police control is greater, which fits $\mathrm{H}_{1}$ regarding ID checks as a tool for crime control.

Regarding the distribution of ID checks by nationality, foreign people (especially those from Western Europe and North Africa) are more likely to be stopped and identified by the police than Spanish people ${ }^{49}$. That is also consistent with research on police stops. ${ }^{50}$ There may be a temptation to explain this fact claiming that foreign people commit more crimes than nationals, but there is no evidence of that. In fact, the evidence points towards the opposite, which is that foreign people are less involved in crime.$^{51}$ For example, based on self-reported juvenile crime data in Spain from the International Self-Report Delinquency Study (ISRD), foreign juveniles report lower or similar levels of delinquency in comparison to Spanish juveniles. In ISRD I the total prevalence of criminal behavior for Spanish juveniles was $68.2 \%$ and for foreigners it was $62 \%$; in ISRD II it was $45.9 \%$ for Spanish and $34.2 \%$ for foreigners; and in ISRD III the results were 37.4 for Spanish and 37.9 for foreigners. ${ }^{52}$ As the hypothesis regarding ID checks as a tool for controlling crime $\left(\mathrm{H}_{1}\right)$ does not fit the results regarding ID checks and nationality, other explanations need to be explored. These findings can be understood in terms of the police overcontrolling ethnic minorities and foreign people, as they are in line with the results of ethnic profiling research in Spain. ${ }^{53}$ Here the conflict perspective and the theories derived from $\mathrm{H}_{2}$ can improve the understanding of why police overcontrol these groups of people.

With reference to the geographical distribution of ID checks in Catalonia, the small number of observations does not allow significant relationships to be identified. It seems that when all the variables are taken into consideration, those that influence the rate of ID checks are

\footnotetext{
${ }^{46}$ FERNÁNDEZ-MOLINA and BARTOLOMÉ (2018), p. 3.

${ }^{47}$ CHOONGH (1998), passim; MCARA and MCVIE (2005), passim; MEDINA (2014), passim; MOONEY and YOUNG (1999), passim.

${ }^{48}$ See notes 36 and 38 .

49 This could not be explained because ID checks are used to (legally) controlling irregular migration as Mossos d'Esquadra does not have these competences (which only have the Cuerpo Nacional de Policía).

${ }^{50}$ For example: BOWLING and PHILLIPS (2007), passim; BRADFORD (2017), passim; BRADFORD and LOADER (2016), passim; GELMAN, FAGAN and KISS (2007), passim; MEDINA (2014), passim; ROSENFELD and FORNAGO (2012), passim.

${ }^{51}$ GARCÍA (2018), passim.

52 FERNÁNDEZ-MOLINA and BARTOLOMÉ (2018), pp. 10-14.

${ }^{53}$ GARCÍA et al. (2013), passim; APDHA and IPAZ-UGR (2016), passim; FRA (2010), passim.
} 


\section{Polít. Crim. Vol. 16, № 31 (Junio 2021), Art. 6, pp. 146-163 [http://politcrim.com/wp-content/uploads/2021/05/Vol16N31A6.pdf]}

the crime rate ${ }^{54}$, the rate of police officers ${ }^{55}$ and the disposable household income. ${ }^{56}$ When the crime rate is replaced by the victimization rate (as an independent indicator of crime), the only variable that has a (positive) significant effect is the number of police officers per 1,000 inhabitants. Taking into account $\mathrm{H}_{1}$, which proposes that ID checks are only related to crime, this hypothesis is not strongly supported by the results. Considering the results of Tables 2, 3 and 4, the small number of observations and the direction of the effects, it can be stated that there are variables (e.g., the rate of police officers, the percentage of young people or the household income) which help to understand the distribution of ID checks other than the crime rate or the victimization rate, as proposed in the order maintenance hypothesis $\left(\mathrm{H}_{2}\right)$.

These results suggest that police activity is not distributed equally among social groups and geographic areas and it is not principally distributed according to criminal activity. This can be seen as an injustice from a distributive justice point of view and it can have negative impact on police legitimacy. If people perceive (distributive or procedural) injustice in police activity, this can lead to a decrease in trust and legitimacy as a consequence of feeling less represented by the police and more disengaged from the group which is represented. ${ }^{57}$

It should be noted that this research has limitations. In the first place, regarding demographic analyses, the number of missing values, which are observations that cannot be classified in any demographic category, is about 20\%. Moreover, these observations contain no information about their previous or current behaviour, which would enable the influence of an individual's behaviour to be isolated from their inclusion in a specific category. In future research it could be interesting to explore other demographic categories such as socioeconomic class and explore these relationships and how the interactions construct the categories of "usual suspects": young people from the working classes and from ethnic minorities. ${ }^{58}$ Secondly, regarding the geographic analysis, the limitations are the small number of observations (59) and the lack of potential explanatory or control variables. Finally, the data do not reflect the fact that there are people who are stopped and subject to ID checks more than once a year (118,050 in 2015 according to the data provided by the Catalan Department of Home Affairs).

\section{Conclusion}

Regarding demographics, ID checks are more frequent among men, young people and foreigners (especially from Eastern Europe, North Africa and Latin America). In terms of the geographic distribution, when controlling for recorded crime, this variable has a significant positive effect as does the rate of police officers. Of the previous sociodemographic variables, only the percentage of young people and household income have statistical significant effect on the rate of people identified by the police at ABP level. When controlling for victimization (as an independent indicator of crime levels), the only significant relationship is the positive correlation with the ratio of police officers. In those areas with a higher ratio of police officers

\footnotetext{
${ }^{54}$ A positive relationship as in PETROCELLI et al. (2003), p. 7.

55 A positive effect as in BRADFORD (2017), p. 132.

56 A negative relationship also similar to BRADFORD (2017), p.132.

${ }^{57}$ BRADFORD (2015), passim; TYLER et al. (2014), passim.

${ }^{58}$ MCARA and MCVIE (2005), passim; MEDINA (2014), passim; MOONEY and YOUNG (1999), passim.
} 
there is a higher proportion of people whose ID was checked by the police (which means that ID checks are a key resource for police officers). While the limitations of the data do not allow the proposed hypotheses to be fully tested, the results seem to indicate that ID checks are more than just (or not primarily) a tool of crime control.

This research appears to indicate that there are factors other than criminal behaviour that can explain the demographic and geographical distribution of ID checks. This can also be seen in other works which have shown that ID checks are not equally distributed within social groups and geographical areas, independent of the effect of criminal behaviour ${ }^{59}$. This can have negative consequences in the form of perceived distributive injustice and a loss of police legitimacy.

If ID checks were uniquely a crime control tool, it could be expected that there would be a more robust relationship between them and criminal behaviour, even when considering other factors $^{60}$. One possible explanation is that the current practice of ID checks is ineffective because it is not distributed solely on the basis of criminal behaviour. However, another possible explanation is that ID checks are not primarily used as a crime control tool but, rather, as an order maintenance tool with the objective of creating and maintaining existing social boundaries between respectable and dangerous categories of citizens ${ }^{61}$.

\footnotetext{
${ }^{59}$ For example, BRADFORD (2017), passim; BRADFORD and LOADER (2016), passim; PETROCELLI et al. (2003), passim; RENAUER (2012), passim.

${ }^{60}$ BRADFORD and LOADER (2016), p. 260.

${ }^{61}$ As defended by BOWLING and MARKS (2015), passim; BRADFORD (2017), passim; BRADFORD and LOADER (2016), passim; DELSOL (2015), passim.
} 


\section{References}

AMNISTÍA INTERNACIONAL (2011): Parad el racismo, no a las personas: perfiles raciales y control de la inmigración en España. Available at: https://tinyurl.com/yexrs96o [last check on April 26, 2021].

APDHA; IPAZ-UGR (2016): Identificaciones basadas en perfil étnico en Granada: estudio realizado mediante observación y entrevistas directas. Available at: https://tinyurl.com/yzpfuhap [last check on April 26, 2021].

LÓPEZ-RIBA, JOSÉ MARÍA (2019). Las identificaciones policiales en España: un análisis crítico desde la criminología (dissertation). Pompeu Fabra University. Available at: http://hdl.handle.net/10803/666512 [last check on April 26, 2021].

BOWLING, Ben; MARKS, Estelle (2015): "Towards a Transnational and Comparative Approach", in: R. DELSOL; M. SHINER (Eds.), Stop and Search: The Anatomy of a Police Power (Basingstoke - Palgrave Macmillan UK). pp. 170-192

BOWLING, Ben; PHILLIPS, Coretta (2007): "Desproportionate and Discriminatory: reviewing the evidence on Police Stop and Search", in: The Modern Law Review, (70,6), pp. 936-961.

BRADFORD, Ben (2015): "Unintended consequences", in: DELSOL R.; SHINER M. (Eds.), Stop and Search: The Anatomy of a Police Power (London, Palgrave Macmillan UK). pp. 102-122.

BRADFORD, BEN (2017): Stop and Search and Police Legitimacy (Abingdon - Routledge).

BRADFORD, Ben; LOADER, Ian (2016): "Police, crime and order: the case of Stop and Search", in: BRADFORD, B.; JAUREGUI, B.; LOADER, I.; STEINBERG, J. (Eds.), The SAGE Handbook of Global Policing (London, SAGE).pp. 241-266.

BRODEUR, JEAN-PAUL (2010): The policing web (New York - Oxford University Press).

CERD (2016): Observaciones finales sobre los informes periódicos vigésimo primero, vigésimo segundo y vigésimo tercero de España (CERD/C/ESP/CO/21-23). Avaliable at: https://tinyurl.com/yz5oqhms [last check on April 26, 2021].

CHOONGH, SATNAM (1998): "Policing the dross: a social disciplinary model of policing", in: British Journal of Criminology, (38, 4), pp 623-634.

DEFENSOR DEL PUEBLO (2013): Informe Anual a las Cortes Generales. Avaliable at: https://tinyurl.com/yhkauhth [last check on April 26, 2021].

DE LA SERNA, CRISTINA (2017): "Control de la inmigración en la vía pública: cuando el color de la piel es la frontera", in: LÓPEZ-SALA, A. and GODENAU, D. (Eds.), Estados de contención, estados de detención: el control de la inmigración irregular en España (Barcelona, Anthropos Editorial). pp. 75-96.

DELSOL, Rebekah (2015): "Effectiveness", in: DELSOL, Rebekah; SHINER, Michael (Eds.), Stop and Search: The Anatomy of a Police Power (London, Palgrave Macmillan UK). pp. 79-101.

ECRI (2018): ECRI Report on Spain (fifth monitoring cycle). Avaliable at: https://tinyurl.com/yhvcyfq6 [last check on April 26, 2021]

ESCUDERO, Laura; GARCÍA, Sergio; SLEPOY, Natalia (2015): "Los controles de identidad como expresión de la seguridad diferencial", in: GARCÍA, Sergio; AVILA, Débora (Coord.), Enclaves de riesgo: gobierno neoliberal, desigualdad y control social (Madrid, Traficantes de Sueños). pp. 179-198. 
FAGAN, Jeffrey; GELLER, Amanda; DAVIES, Garth; WEST, Valerie (2010): "Street Stops and Broken Windows Revisited: the Demography and Logic of Proactive Policing in a Safe and Changing City", in: RICE, Stephen K.; WHITE, Michael D. (Eds.), Race, ethnicity and policing: new and essential readings (New York - New York University Press). pp. 309-348.

FERNÁNDEZ-MOLINA, Esther; BARTOLOMÉ, Raquel (2018): "Juvenile crime drop: What is happening with youth in Spain and why?", in: European Journal of Criminology (OnlineFirst), pp. 1-26.

FRA (2010): Informe «Data in Focus»: Identificaciones policiales y minorías. Avaliable at: https://tinyurl.com/ygmtw342 [last check on April 26, 2021].

GARCÍA, Elisa (2018): Enfoque criminológico de las migraciones (Madrid - Síntesis).

GARCÍA, Elisa, ARENAS, Lorea; MILLER, Joel (2016): Identificaciones policiales y discriminación racial en España: Evaluación de un programa para su reducción (Valencia, Tirant lo Blanch).

GARCÍA, SERGIO (2012): “Dispositivo securitario en un espacio barrial. La práctica policial de los controles de identidad", in: ARBOR Ciencia, Pensamiento y Cultura (188), pp. 573-590.

GARCÍA, José; BRADFORD, Ben; GARCÍA, José Antonio; GASCÓN, Andrés; LLORENTE, Antoni (2013): Identificación policial por perfil étnico en España: Informe sobre experiencias y actitudes en relación con las actuaciones policiales (Valencia, Tirant lo Blanch).

SCHMITT, Maggie; PERNAS, Begoña (2008): Pasos hacia la igualdad: El Proyecto STEPSS (Strategies for Effective Police Stop and Search) en España. Available at: https://tinyurl.com/yfvd69x2 [last check on April 26, 2021].

GELMAN, Andrew; FAGAN, Jeffrey; KISS, Alex (2007): "An Analysis of the New York City Police Department's "Stop-and-Frisk" Policy in the Context of Claims of Racial Bias", in: Journal of the American Statistical Association (102,479), pp. 813-823.

MARTÍNEZ, Margarita; SÁNCHEZ, José Miguel (2013): "Controles de identidad, detenciones y uso del perfil étnico en la persecución penal y castigo del inmigrante "sin papeles": ilegalidad e inconstitucionalidad de determinadas prácticas policiales.”, in: ÁLVAREZ GARCÍA, Francisco Javier; COBOS GÓMEZ DE LINARES, Miguel Ángel; GÓMEZ PAVÓN, Pilar; MANJÓN-CABEZA OLMEDA, Araceli; MARTÍNEZ GUERRA, Amparo (Eds.), Libro homenaje al prof. Luis Rodíguez Ramos (Valencia, Tirant lo Blanch). pp. 1025-1054.

MCARA, Lesley; MCVIE, Susan (2005): "The usual suspects? Street-life, young people and the police", in: Criminal Justice (5,1), pp. 5-36.

MEDINA, Juan José (2014): "Police-initiated contacts: young people, ethnicity, and the "usual suspects."”, in: Policing and Society (24,2), pp. 208-223.

MINISTRY OF HOME AFFAIRS (2016): Anuario Estadístico del Ministerio del Interior 2015. Avaliable at: https://tinyurl.com/yht248hv [last check on April 26, 2021].

MOONEY, Jayne; YOUNG, Jock (1999): Social exclusion and criminal justice: ethnic minorities and stop and search in North London. Avaliable at: https://tinyurl.com/ykxd3vpg [last check on April 26, 2021].

MOSSOS D’ESQUADRA (2018): Ayuda sobre datos abiertos Mossos. Avaliable at: https://tinyurl.com/yg2yas9a [last check on April 26, 2021].

MURRAY, Kath (2014): "Non-statutory stop and search in scotland", in: SCCJR Briefing 
(6/2014), pp. 1-8.

BUSINESS AND LABOUR OBSERVATORY (2016): atur per comarques i municipis: dades de desembre de 2015. Avaliable at: https://tinyurl.com/yfxk4tsc [last check on April 26, 2021].

PEAUCELLIER, Sophie; SPILKA, Stanislas; JOBARD, Fabien; LÉVY, René (2016): “Les contrôles d'identité et les jeunes Parisiens: une exploitation du volet parisien de l'enquête Escapad 2010", in: Questions Pénales (XXIX, 2), pp. 1-6.

PETROCELLI, Mathew, PIQUERO, Alex R. and SMITH, Michael R. (2003): "Conflict theory and racial profiling: an empirical analysis of police traffic stop data", in: Journal of Criminal Justice (31), pp. 1-11.

REINER, Robert (2010): The politics of the police. 4th ed. (New York, Oxford University Press).

RENAUER, Brian C. (2012): "Neighborhood variation in police stops and searches: a test of consensus and conflict perspectives", in: Police Quarterly (15, 3), pp. 219-240.

RÍOS, Julián, SEGOVIA, José Luis; ETXEBARRIA, Xabier (2015): Manual para la defensa de los derechos y las libertades ante la intervención de la policía (Madrid, Universidad Pontificia Comillas).

ROSENFELD, Richard; FORNAGO, Robert (2012): "The Impact of Police Stops on Precinct Robbery and Burglary Rates in New York City, 2003-2010", in: Justice Quarterly, (31, 1), pp. 96-122.

TIRATELLI, Matteo; QUINTON, Paul; BRADFORD, Ben (2018): "Does Stop and Search deter crime? Evidence from ten years of London-wide data", in: British Journal of Criminology $(58,5)$, pp. 1212-1231.

TYLER, Tom R., FAGAN, Jeffrey and GELLER, Amanda (2014): "Street stops and police legitimacy: Teachable Moments in Young Urban Men's Legal Socialization", in: Journal of Empirical Legal Studies (11, 4), pp. 751-785. 